\title{
Non-Audit Service Provision and Its Effect on Auditors' Independence and Audit Quality
}

\author{
Billy Ivan Tansuria \\ Faculty of Economics and Business, Universitas Klabat (UNKLAB), Indonesia, \\ E-mail: billy_tansuria@yahoo.com
}

\begin{abstract}
This research examines auditors' perceptions on the provision of non-audit services (NAS) to audit clients towards auditor independence and audit quality. It is a descriptive study that mainly investigates whether auditors perceive the provision of NAS to impair their independence, enhances audit quality, or whether it has no effect on auditor independence. This research utilized a questionnaire that was sent to external auditors that are currently working in public accounting firms in Indonesia. Seventeen auditors responded to the online survey. It was found that auditors somewhat perceive the provision of NAS to impair their independence, as well as enhance audit quality. In addition, they disagree that it has no effect on independence. Moreover, this study found no significant difference in auditors' perception when gender, working experience, position, educational background, the experience of NAS provision, and age group were considered.

Key words

Audit Quality, Auditor Independence, Non-Audit Service Provision, Indonesia.

\begin{tabular}{|c|c|c|}
\hline Received: & 09 Jun 2020 & (C) The Authors 2020 \\
\hline Revised: & 12 Jul 2020 & Published by Human Resource Management Academic Research Society (www.hrmars.com) \\
\hline $\begin{array}{l}\text { Accepted: } \\
\text { ed Online: }\end{array}$ & $\begin{array}{l}18 \text { Aug } 2020 \\
26 \text { Aug } 2020\end{array}$ & $\begin{array}{l}\text { This article is published under the Creative Commons Attribution (CC BY } 4.0 \text { ) license. Anyone may } \\
\text { reproduce, distribute, translate and create derivative works of this article (for both commercial and } \\
\text { non-commercial purposes), subject to full attribution to the original publication and authors. The full } \\
\text { terms of this license may be seen at: http://creativecommons.org/licences/by/4.0/legalcode }\end{array}$ \\
\hline
\end{tabular}
\end{abstract}

\section{Introduction and literature review}

One of the most highly debated audit independence issues has been the provision of non-audit services (NAS) by audit firms to their audit clients. Strong arguments have been made that such services create an economic bond between auditor and client, impairing an auditor's independence. On the other hand, equally strong opinions have been expressed that the provision of NAS increases an auditor's knowledge of the client's business, resulting in a more effective audit. Empirical studies of the potential relation between audit quality and NAS levels have found little, if any, evidence to support the former position, and some evidence to support the latter opinion (Causholli et al., 2015).

During the last 20 years, various NAS rendered by auditing firms have emerged and have been widely adopted by companies around the world. This was due to the expansion and complication of the globalization, spreading of multinational companies, and the improvements in information technology (Khasharmeh \& Desoky, 2018). The U.S. regulators have stated nine types of NAS services, which include bookkeeping, design, and implementation of financial information systems and valuation services or fairness opinions, internal auditing services, planning of human resources, actuarial services, and legal services (Sarbanes \& Oxley, 2002). Nowadays, many companies have acquired NAS services such as computer hardware and software installation, human resources planning, bookkeeping, tax return preparation, investment banking, internal audit out-sourcing, and finally, management advisory services (Jenkins \& Krawczyk, 2011). Furthermore, according to Brierley \& Gwilliam (2003), since the globalization in 
accounting and assurance service, it has formed 'the multidisciplinary nature of audit firms' which would present audit and NAS to audit clients. Therefore, Quick \& Warming-Rasmussen (2005) argued that the practice had become one of the significant issues concerning the possible auditor independence dilemma.

The extension of NAS services to the clients has raised inquiries about whether auditing firms can sustain their independence while offering NAS to audit clients. Without independence, an audit cannot achieve its goals, which is the essential requirement for an auditor to be able to perform an audit. The auditor in public practices must be free of bias with respect to the client and must be recognized as independent by users of the audit report. Performing audit and NAS for the same client might cause a lack of independence for the auditor, because this may create a working relationship that is too close between the auditor and the client. Lindsay et al. (1987) investigated the influence of providing a number of services (i.e., preparation of accounts, executive search, and accounting systems design) on auditor independence in the Canadian environment. They concluded that accounting systems design was seen as the smallest threat to auditor independence. However, they found that about a third of the respondents considered the other two services, preparation of accounts and executive search, to be making an auditor dependent on the client. This expansion of services is expected to improve the firm's competitiveness, maintain continuous growth, and satisfy customers. In line with this, Khasharmeh \& Desoky (2018) also found that the majority of German auditors believed that auditor independence would be abused when auditors offer widespread accounting consultancy or services.

This study is conducted to provide empirical evidence on NAS provision toward auditor's independence. Furthermore, this study also investigated the impact of providing NAS upon the quality of the audit. This study contributes to the accounting and auditing literature by filling the gap in the existing literature because there are only a few publications that directly investigate NAS provision in developing countries such as in Indonesia. Hence, this study focuses on investigating the perceptions of external auditors working in public accounting firms in Indonesia on the issue of providing NAS to an audit client and its influence upon auditor independence and audit quality. More specifically, the hypotheses of this study are as follows:

$H_{\mathrm{a}} 1$ : Provision of NAS impairs auditor independence

$H_{\mathrm{a}}$ 2: Provision of NAS enhances audit quality

$H_{\mathrm{a}} 3$ : Provision of NAS has no impact on auditor independence

$H_{a} 4$ : There is a significant difference between auditor perception when the auditors are grouped according to gender, working experience, position, educational background, the experience of NAS provision, and age group.

\section{Methodology of research}

This study aims to examine the effect of NAS provision to audit clients on auditor independence and audit quality. It involves a survey of auditor perception using an online questionnaire. The online questionnaire is prepared using Google form, and the link was sent through social media. It is distributed to external auditors who are currently working in public accounting firms in Indonesia. Using the convenience sampling technique, the questionnaire is sent to whomever the researcher has access. However, given the limited time and contact, only seventeen auditors responded to the questionnaire sent.

The questionnaire is adopted from Khasharmeh and Desoky (2018). It comprises of three sections, in which Section 1 (i.e., questions 1 to 11 ) measures whether the provision of NAS impairs the auditor independence, Section 2 (i.e., questions 12 to 22) measures whether the provision of NAS improves audit quality, while Section 3 (i.e., questions 23 to 26) measures whether the provision of NAS does not affect auditor independence. The questionnaire utilizes a five-point Likert scale (i.e., $1=$ strongly disagree, $2=$ disagree, 3 = somewhat agree, $4=$ agree, and $5=$ strongly agree). The demographic section is also included to examine whether different perspectives may be attributed to gender, working experience, position, educational background, the experience of NAS provision, and age group. 


\section{Results and discussions}

\subsection{Demographic Data of the Respondents}

Demographic analysis in Table 1 shows that a total of seventeen external auditors responded to the online survey. Among the respondents, nine (52.9\%) are female, and eight (47.1\%) are male. Table 1 also shows that majority of the respondents have been working as an auditor for less than five years (i.e., twelve respondents or $70.6 \%$ ) and they are in the position as a junior auditor (i.e., ten respondents or $58.8 \% \%$ ). Most of the auditors have a bachelor's degree (i.e., twelve respondents or $70.6 \%$ ). The majority are never engaged in providing NAS to their audit clients (i.e., eleven respondents or $64.7 \%$ ), and most of them are in the age group of 21 to 30 (i.e., eleven respondents or $64.7 \%$ ).

Table 1. Frequency Analysis

\begin{tabular}{|c|c|c|}
\hline Variable & No of Respondents & Percentage \\
\hline \multicolumn{3}{|l|}{ Gender } \\
\hline Female & 9 & 52.9 \\
\hline Male & 8 & 47.1 \\
\hline Total & 17 & 100.0 \\
\hline \multicolumn{3}{|c|}{ Working Experience } \\
\hline$<5$ years & 12 & 70.6 \\
\hline 5 - 10 years & 3 & 17.6 \\
\hline 11 - 20 years & 2 & 11.8 \\
\hline Total & 17 & 100.0 \\
\hline \multicolumn{3}{|l|}{ Position } \\
\hline Junior Auditor & 10 & 58.8 \\
\hline Senior Auditor & 3 & 17.6 \\
\hline Audit Manager & 3 & 17.6 \\
\hline Partner & 1 & 5.9 \\
\hline Total & 17 & 100.0 \\
\hline \multicolumn{3}{|c|}{ Educational Background } \\
\hline Bachelor & 12 & 70.6 \\
\hline Masters & 4 & 23.5 \\
\hline Others & 1 & 5.9 \\
\hline Total & 17 & 100.0 \\
\hline \multicolumn{3}{|l|}{ NAS Provision } \\
\hline Yes & 6 & 35.3 \\
\hline No & 11 & 64.7 \\
\hline Total & 17 & 100.0 \\
\hline \multicolumn{3}{|l|}{ Age Group } \\
\hline $21-30$ & 11 & 64.7 \\
\hline $31-40$ & 6 & 35.3 \\
\hline Total & 17 & 100.0 \\
\hline
\end{tabular}

\subsection{Auditors' Perceptions}

Before verifying the hypotheses, the reliability test was conducted to check the internal consistency of the questionnaire. To measure the reliability of items in the questionnaire, Cronbach's alpha test was performed. The results in Table 2 shows that the Cronbach's Alpha of the 26 items in the questionnaire is 0.837 , which is higher than 0.7 , the general rule of thumb. Therefore, it can be concluded that the questionnaire is highly reliable in measuring auditors' perceptions on the effect of NAS provision to the audit client.

Table 2. Reliability Test

\begin{tabular}{cc}
\hline Cronbach's Alpha & N of Items \\
\hline 0.837 & 26 \\
\hline
\end{tabular}




\subsection{Descriptive Statistics}

Table 3 presents the descriptive statistics on each question in the questionnaire, classified by the three sections. Based on the decision criteria, the mean score greater than 3 indicates that the statement is essential as perceived by the auditors. Under Section 1, Q6 received the highest mean score (i.e., 3.94), indicating the importance of this question. Respondents perceived "an auditor should not be allowed to participate in the foundation of the corporation that is being audited by him or to be a member of an administrative or advisory position." Q14 and Q20 under Section 2 received the highest score (i.e., 3.47); they respectively indicate that auditors highly regard "the provision of NAS activities enhances the auditor's ability to learn more clients, thereby helping to ensure that they satisfy their obligation to conduct a better audit," as well as "certain frauds might have been prevented or detected if NAS had been provided to the client or if better communication had occurred between NAS personnel and the audit engagement team." Under Section 3, Q24 received the highest mean score (i.e., 3.29), indicating the importance of this particular question, among others. Auditors perceived "the provision of NAS does not necessarily damage auditor independence or the quality of NAS."

Given that the data is not normally distributed, non-parametric tests were used to verify the hypotheses. In particular, the significant difference in auditors' perception is tested using the Chi-Square for one sample test. Most of the Chi-square for the 26 questions is not significant $(p>0.05)$ except that of Q2, Q3, Q4, Q9, Q16, Q20, and Q24. This indicates that most of the responses are equally dispersed among the different levels of agreement.

Table 3. Descriptive Statistics per Question

\begin{tabular}{ccccccccc}
\hline Questions & $\mathbf{N}$ & Min & Max & Mean & SD & Chi-Square & df & Asymp. Sig. \\
\hline Q1 & 17 & 2 & 4 & 2.71 & 0.849 & 2.941 & 2 & 0.230 \\
Q2 & 17 & 1 & 5 & 2.59 & 1.004 & 13.294 & 4 & 0.010 \\
Q3 & 17 & 1 & 5 & 2.65 & 0.931 & 12.706 & 4 & 0.013 \\
Q4 & 17 & 1 & 4 & 2.71 & 0.772 & 9.118 & 3 & 0.028 \\
Q5 & 17 & 1 & 4 & 2.71 & 0.849 & 5.353 & 3 & 0.148 \\
Q6 & 17 & 2 & 5 & 3.94 & 1.029 & 5.353 & 3 & 0.148 \\
Q7 & 17 & 1 & 5 & 3.24 & 1.147 & 4.471 & 4 & 0.346 \\
Q8 & 17 & 1 & 4 & 2.18 & 0.883 & 4.412 & 3 & 0.220 \\
Q9 & 17 & 2 & 5 & 3.18 & 0.809 & 8.176 & 3 & 0.043 \\
Q10 & 17 & 3 & 5 & 3.82 & 0.809 & 0.824 & 2 & 0.662 \\
Q11 & 17 & 2 & 5 & 3.41 & 1.176 & 0.176 & 3 & 0.981 \\
Q12 & 17 & 2 & 4 & 3.29 & 0.686 & 3.647 & 2 & 0.161 \\
Q13 & 17 & 2 & 5 & 3.35 & 0.996 & 2.059 & 3 & 0.560 \\
Q14 & 17 & 2 & 5 & 3.47 & 0.943 & 3.471 & 3 & 0.325 \\
Q15 & 17 & 1 & 4 & 2.76 & 0.970 & 3.000 & 3 & 0.392 \\
Q16 & 17 & 1 & 4 & 2.06 & 0.827 & 8.176 & 3 & 0.043 \\
Q17 & 17 & 2 & 5 & 3.41 & 1.004 & 3.000 & 3 & 0.392 \\
Q18 & 17 & 1 & 4 & 2.65 & 0.996 & 2.059 & 3 & 0.560 \\
Q19 & 17 & 1 & 4 & 3.06 & 0.966 & 4.412 & 3 & 0.220 \\
Q20 & 17 & 2 & 5 & 3.47 & 0.874 & 8.176 & 3 & 0.043 \\
Q21 & 17 & 1 & 4 & 2.88 & 1.111 & 3.000 & 3 & 0.392 \\
Q22 & 17 & 2 & 5 & 3.47 & 0.943 & 3.471 & 3 & 0.325 \\
Q23 & 17 & 1 & 4 & 2.65 & 1.169 & 0.647 & 3 & 0.886 \\
Q24 & 17 & 1 & 5 & 3.29 & 0.985 & 9.765 & 4 & 0.045 \\
Q25 & 17 & 2 & 5 & 2.82 & 0.951 & 6.294 & 3 & 0.098 \\
Q26 & 17 & 1 & 4 & 2.94 & 0.966 & 3.471 & 3 & 0.325 \\
\hline
\end{tabular}

The descriptive statistics for each section can be seen in Table 4. It is shown that Section 1 has a mean score of 3.011, with a standard deviation of 0.560 . This means that the respondents somewhat agree that the provision of NAS impairs auditor independence, which supports the first hypothesis. The standard deviation is less than half of the mean, which means that there is no dispersion among auditors' perceptions regarding the impact of NAS provision on auditor independence. This particular result supports the study of Joshi, Bremser, Hemalatha, and Al-Mudhaki (2007) and Khasharmeh and Desoky (2018), which also found that the provision of NAS impairs auditor independence. 
Table 4 also shows that Section 2 of the questions has a mean score of 3.080 and a standard deviation of 0.560 , which is also less than half of the mean. This particular result indicates that auditors somewhat perceive the provision of NAS to enhance audit quality, which supports the second hypothesis. There is also no dispersion found among auditor's perception on this matter. On the other hand, section 3 , as shown in Table 4, has a mean score of 2.927 , with a standard deviation of 0.695 , which is also less than half of the mean. The mean score is the lowest among the three sections. This indicates that auditors disagree that the provision of NAS has no impact on auditor independence; thus, the third hypothesis is not supported. There is no dispersion found on the perception of the auditors.

The Chi-square of each section is not significant ( $p$-value $>0.05)$, which means that the answers are equally distributed among different levels of agreement criteria. Overall, based on the results of the three sections, auditors support the argument that the provision of NAS impairs auditor independence (Section 1 ), and improves audit quality (Section 2). However, they disagree that the provision of NAS has no impact on auditor independence (Section 3).

Table 4. Descriptive Statistics per Section

\begin{tabular}{lcccccccc}
\hline \multicolumn{1}{c}{ Section of Questions } & N & Min & Max & Mean & SD & Chi-Square & df & Asymp. Sig. \\
\hline Section 1 (Q1-11) & 17 & 2.18 & 4.27 & 3.011 & 0.560 & 2.059 & 11 & 0.998 \\
Section 2 (Q12-22) & 17 & 1.73 & 3.82 & 3.080 & 0.560 & 3.588 & 9 & 0.936 \\
Section 3 (Q23-26) & 17 & 1.75 & 4.00 & 2.927 & 0.695 & 5.765 & 8 & 0.674 \\
\hline
\end{tabular}

\subsection{Correlation Analysis}

The Pearson Correlation coefficients in Table 5 show that there is no significant correlation between the demographic variables (i.e., gender, working experience, position, educational background, the experience on NAS provision, age) and the three sections of questions. The small sample size might affect the results.

Table 5. Correlation Coefficients

\begin{tabular}{lccccccccc}
\hline & Gender & Exp. & Position & Education & Provision & Age & Section 1 & Section 2 & Section 3 \\
\hline Gender & 1 & 0.120 & 0.044 & -0.045 & -0.044 & 0.044 & -0.157 & 0.255 & 0.409 \\
Exp. & 0.120 & 1 & $.718^{* *}$ & $.785^{* *}$ & $-.629^{* *}$ & $.629^{* *}$ & -0.126 & -0.202 & 0.033 \\
Position & 0.044 & $.718^{* *}$ & 1 & $.643^{* *}$ & $-.614^{* *}$ & $.614^{* *}$ & -0.251 & -0.346 & -0.330 \\
Education & -0.045 & $.785^{* *}$ & $.643^{* *}$ & 1 & $-.723^{* *}$ & $.723^{* *}$ & -0.329 & -0.296 & 0.002 \\
Provision & -0.044 & $-.629^{* *}$ & $-.614^{* *}$ & $-.723^{* *}$ & 1 & $-1.000^{* *}$ & 0.138 & -0.097 & -0.218 \\
Age & 0.044 & $.629^{* *}$ & $.614^{* *}$ & $.723^{* *}$ & $-1.000^{* *}$ & 1 & -0.138 & 0.097 & 0.218 \\
Section 1 & -0.157 & -0.126 & -0.251 & -0.329 & 0.138 & -0.138 & 1 & 0.399 & -0.264 \\
Section 2 & 0.255 & -0.202 & -0.346 & -0.296 & -0.097 & 0.097 & 0.399 & 1 & $.494^{*}$ \\
Section 3 & 0.409 & 0.033 & -0.330 & 0.002 & -0.218 & 0.218 & -0.264 & $.494^{*}$ & 1 \\
\hline
\end{tabular}

** Correlation is significant at the 0.01 level (2-tailed); * Correlation is significant at the 0.05 level (2-tailed).

\subsection{Analysis of Variance}

Table 6 presents the results of the Kruskal-Wallis test, a non-parametric test for independent samples. It is found that there is no statistical difference in auditor perceptions on the set of questions in each section when grouped according to gender, working experience, position, educational background, the experience of NAS provision, and age group. Hence, the fourth hypothesis is not supported. The results in this section confirm those of the previous test regarding the correlation coefficient analysis.

Table 6. Statistical Analysis for Various Groups

\begin{tabular}{lccc}
\hline Section of Questions & Chi-Square & df & Asymp. Sig. \\
\hline Gender & & & \\
Section 1 & 9.357 & 10 & 0.499 \\
Section 2 & 9.930 & 10 & 0.477 \\
Section 3 & 10.866 & 10 & 0.368 \\
Working Exp. & & & \\
Section 1 & 0.551 & 2 & 0.759 \\
Section 2 & 0.962 & 2 & 0.618
\end{tabular}




\begin{tabular}{lccc}
\hline Section of Questions & Chi-Square & df & Asymp. Sig. \\
\hline Section 3 & 2.594 & 2 & 2.730 \\
Position & & & \\
Section 1 & 1.957 & 3 & 0.581 \\
Section 2 & 3.647 & 3 & 0.302 \\
Section 3 & 3.195 & 3 & 0.363 \\
Education & & & \\
Section 1 & 2.121 & 2 & 0.346 \\
Section 2 & 2.435 & 2 & 0.296 \\
Section 3 & 0.254 & 2 & 0.881 \\
NAS Provision & & & \\
Section 1 & 0.023 & 1 & 0.880 \\
Section 2 & 0.433 & 1 & 0.511 \\
Section 3 & 0.582 & 1 & 0.446 \\
Age Group & & & \\
Section 1 & 0.023 & 1 & 0.880 \\
Section 2 & 0.433 & 1 & 0.511 \\
Section 3 & 0.582 & 1 & 0.446 \\
\hline
\end{tabular}

\section{Conclusions}

This study examines auditors' perception on the impact of providing NAS to audit clients on auditor independence and audit quality. A questionnaire is adopted and distributed to external auditors in Indonesia. Seventeen respondents participated in the survey. Using non-parametric tests, it is found that auditors perceived the provision of NAS to somewhat impair auditor independence. In addition, based on their perception, auditors considered the provision of NAS to enhance the quality of the audit. It is also found that auditors disagree that the provision of NAS does not affect auditor independence. The correlation coefficient analysis and the test of variance both show that there is no significant difference in auditors' perception towards the set of questions in each section. This study is limited to a small number of respondents that work in public accounting firms in Indonesia; hence, it has low external validity. Future studies could broaden the sample to include accountants and financial managers to examine the perception from the side of auditees. Future research could also investigate whether auditor reputation has a significant difference on auditors' perception towards the provision of NAS, by comparing those that work in big-four and non-big-four public accounting firms.

\section{References}

1. Brierley, J. A., \& Gwilliam, D. R. (2003). Human resource management issues in audit firms: A research agenda. Managerial Auditing Journal, 18(5), 431-438.

2. Causholli, M., Chambers, D. J., \& Payne, J. L. (2015). Does selling non-audit services impair auditor independence? New research says, "yes." Current Issues in Auditing, 9(2), 1-6.

3. Jenkins, J. G., \& Krawczyk, K. (2011). The influence of non-audit services on perceptions of auditor independence. Journal of Applied Business Research.

4. Joshi, P. L., Bremser, W. G., Hemalatha, J., \& Al-Mudhaki, J. (2007). Non-audit services and auditor independence: Empirical findings from Bahrain. International Journal of Accounting, Auditing and Performance Evaluation, 4(1), 57-89.

5. Khasharmeh, H., \& Desoky, A. M. (2018). Does the provision of non-audit services affect auditor independence and audit quality? Evidence from Bahrain. Asian Academy of Management Journal of Accounting and Finance, 14(1), 25-55.

6. Lindsay, D., Rennie, M., Murphy, G., \& Silvester, H. (1987). Independence of external auditors: A Canadian perspective. Advances in International Accounting, 1(1), 169-189.

7. Quick, R., \& Warming-Rasmussen, B. (2005). The impact of MAS on perceived auditor independence-some evidence from Denmark. Accounting Forum, 29(2), 137-168.

8. Sarbanes, P., \& Oxley, M. Sarbanes-Oxley Act of 2002, Washington DC: U.S. Congress $\S(2002)$. 